\title{
ANALISIS DAYA TARIK UNGGULAN EKOWISATA DUSUN BAMBU BANDUNG, JAWA BARAT
}

\author{
Annisa Retno Utami' ${ }^{1}$ Farida Farida ${ }^{2}$ \\ Fakultas Ekonomi dan Bisnis, Universitas Sahid \\ Jl. Soepomo No 84, Jakarta Selatan \\ Email Korespondensi: annisaretno4@gmail.com
}

\begin{abstract}
ABSTRAK
Industri pariwisata saat ini mengalami perkembangan dan pertumbuhan sangat pesat, karena pada umumnya orang membutuhkan hiburan dan wisata untuk merefreshing pikiran akibat rutinitas bekerja dan kepenatan. Bandung merupakan kota yang menyimpan sejuta pesona. Salah satu destinasi favorit wisatawan di Bandung adalah Dusun Bambu yang berlokasi di kaki Gunung Burangrang. Tujuan dari penelitian ini yaitu untuk mengetahui potensi daya tarik unggulan yang dimiliki oleh Dusun Bambu. Sampel dari penelitian ini yaitu 100 wisatawan. Dalam penelitian ini yang dapat dijadikan sampel yaitu wisatawan yang sudah mengunjungi Dusun Bambu Bandung dan Wisatawan Domestik dan berusia $>17$ Tahun. Teknik pengumpulan data dilakukan dengan Observasi, Wawancara, Kuesioner dan Studi Literatur. Berdasarkan hasil penelitian faktor tertinggi yang menjadi daya tarik wisatawan untuk berkunjung yaitu dari konsep yang diberikan pada tempat untuk makan dan minum atau kafe, sebanyak $47 \%$ pengunjung menyukai konsep dari Lutung Kasarung, karena menurut mereka ini konsep yang unik dan antimainstream sehingga konsep ini menjadikan daya tarik tersendiri untuk wisatawan berkunjung ke Dusun Bambu. Sedangkan untuk faktor terendah pada biaya yang dibutuhkan ketika ingin berkunjung ke Dusun Bambu, dikarenakan harga makanan dan minuman yang cukup mahal.
\end{abstract}

Kata Kunci: Daya Tarik Wisata, Ekowisata, Wisata Bandung, Dusun Bambu Bandung

\begin{abstract}
The tourism industry is currently experiencing rapid growth and growth, because in general people need entertainment and tourism to refresh their minds due to work routines and fatigue. Bandung is a city that holds a million charms. One of the favorite tourist destinations in Bandung is Dusun Bambu, located at the foot of Mount Burangrang. The purpose of this study is to find out the potential for superior attraction possessed by Dusun Bambu. The sample from this study is 100 tourists. In this study, samples that can be taken are tourists who have visited Dusun Bambu Bandung and Domestic Travelers and are> 17 years old. Data collection techniques are carried out by Observation, Interview, Questionnaire and Literature Study. Based on the results of the highest factor research that attracts tourists to visit, from the concept given to places to eat and drink or cafes, $47 \%$ of visitors like the concept of Lutung Kasarung, because according to them this concept is unique and anti-stream so that this concept makes power special attraction for tourists visiting the Bamboo Village. Whereas the lowest factor is the cost needed to visit Dusun Bambu, because the price of food and drinks is quite expensive.
\end{abstract}

Keywords: Tourist Attractions, Ecotourism, Tourism Bandung, Dusun Bambu Bandung 


\section{PENDAHULUAN}

Industri pariwisata saat ini mengalami perkembangan dan pertumbuhan sangat pesat, karena pada umumnya orang membutuhkan hiburan dan wisata untuk merefreshing pikiran akibat rutinitas bekerja dan kepenatan. Saat ini banyak pandangan dari masyarakat bahwa pariwisata bukan lagi menjadi sesuatu hal yang asing dan tabu, namun sudah menjadi bagian dan gaya hidup yang dapat dilakukan oleh semua masyarakat dan semua kalangan yang memiliki keinginan dan kebutuhan untuk berpergian untuk berekreasi ke darah tujuan wisata.

Salah satu yang saat ini menjadi destinasi wisata yaitu Kota Bandung. Bandung merupakan kota yang menyimpan sejuta pesona. Salah satu destinasi favorit wisatawan di Bandung adalah Dusun Bambu yang berlokasi di kaki Gunung Burangrang yang berada di Jalan Kolonel Masturi KM 11, Cisarua, Kecamatan Lembang, Kabupaten Bandung Barat. Misi dari objek wisata Dusun Bambu yaitu 7E yang merupakan singkatan dari Edukasi, Ekonomi, Etnologi, Etika, Estetika, dan Entertainment. Dusun Bambu memiliki daya tarik utama pada keindahan alamnya. Lokasinya yang berada di kaki gunung, menjadikan objek wisata Dusun Bambu ini berhawa sejuk. Di Dusun Bambu wisatawan dapat menikmati pemandangan pesawahan, danau, kawasan hutan pinus, dll.

Aktivitas yang dapat dinikmati wisatawan yang menjadi daya tarik tersendiri dibandingkan dengan objek wisata lainnya yaitu adanya Cafe Burangrang yang dapat dinikmati oleh wisatawan sebagai tempat makan/resto yang dapat dinikmati sambil melihat pemadangan. Selain Cafe Burangrang ada juga Lutung Kasarung sebagai kafe yang cukup unik, karena menawarkan konsep yang sangat antimainstream dari desainnya. Wisatawan/ pengunjung dapat menikmati hidangan makanan/minuman dalam bentuk kapsul raksasa yang terbuat dari akar ranting pohon. Selain kafe, ada juga Pasar Khatulistiwa jika pengunjung ingin berbelanja aneka sayuran segar dan buahbuahan, wisata kuliner dan wisata belanja. Selain itu ada Saung Purbasari yang merupakan saung yang dapat dinikmati oleh 6-12 orang untuk menikmati udara segar dan pemadangan danau. Jika pengunjung ingin bermain dengan permainan tradisional maka dapat menikmati Bamboo Play Ground. Selain permainan di Dusun Bambu pengunjung dapat menginap di Villa Kampung Layung, Eagle Camp (Camping Ground). Sehingga daya tarik yang ada di Dusun Bambu bukan hanya keindahan alamnya saja, namun dapat dinikmati untuk bersantai dengan mengunjungi kafenya dan bersaintai untuk menginap di Villa/Camping di Dusun Bambu. Tujuan dari penelitian ini yaitu untuk mengetahui potensi daya tarik unggulan yang dimiliki oleh Dusun Bambu.

Pariwisata merupakan perjalanan berkeliling ataupun perjalanan yang dilakukan berkali-kali berputar-putar dari suatu tempat ke tempat lain. Menurut Yoeti (2010) Pariwisata merupakan suatu aktivitas manusia yang dilakukan secara sadar yang mendapat pelayanan secara bergantian diantara orang-orang dalam suatu negara itu sendiri atau di luar negeri untuk mencari kepuasan yang beraneka ragam dan berbedabeda dengan apa yang dialaminya. Menurut Damanik (2006), pariwisata sebagai perpindahan orang untuk sementara waktu ke destinasi diluar tempat tinggal dan tempat bekerjanya untuk melaksanakan kegiatan selama di destinasi dan penyiapan fasilitas untuk memenuhi kebutuhan.

Daya tarik produk wisata merupakan paket yang tidak hanya tentang keindahan atau eksotisme suatu tempat wisata, tapi dalam arti yang lebih luas, yang mencangkup daya tarik, fasilitas, dan akses menuju tempat wisata (Ali, 2012). Menurut Warpani 
(2007) daya tarik wisata sebagai segala sesuatu yang memicu seseorang atau sekelompok orang untuk mengunjungi suatu tempat karena sesuatu yang memiliki makna tertentu, misalnya: lingkungan alam, peninggalan atau tempat sejarah, peristiwa tertentu sedangkan menurut Basiya dan Rozak (2012), daya tarik tempat tujuan wisata merupakan motivasi utama bagi pengunjung untuk melakukan kunjungan wisata. Menurut destinasinya wisata dikelompokkan menjadi empat daya tarik, yaitu :

1. Daya tarik wisata alam (natural attraction) yang meliputi pemandangan alam daratan, pemandangan alam lautan, pantai, iklim dan cuaca.

2. Daya tarik wisata berupa arsitektur bangunan (building attraction) yang meliputi bangunan dan arsitektur bersejarah, bangunan dan arsitektur modern, arkeologi.

3. Daya tarik wisata yang dikelola khusus (managed visitor attractions), yang meliputi tempat peninggalan kawasan industri seperti yang ada di Inggris, Theme Park di Amerika, Darling Harbour di Australia.

4. Daya tarik wisata budaya (culturalattraction) yang meliputi teater, museum, tempat bersejarah, adat istiadat, tempat-tempat religius, peristiwa-peristiwa khusus seperti festival dan drama bersejarah (pageants) dan heritage seperti warisan peninggalan budaya.

5. Daya tarik wisata sosial seperti gaya hidup penduduk di tempat tujuan wisata. Menurut Middleton dalam Sopyan (2015) bahwa total produk wisata adalah suatu paket atau kemasan yang meliputi komponen barang berwujud dan tidak berwujud, yang digunakan untuk kegiatan-kegiatan di tempat tujuan wisata dan paket tersebut diperepsikan oleh pengunjung sebagai suatu pengalaman yang dapat dibeli dengan harga tertentu.

\section{METODE PENELITIAN}

\section{Populasi dan Sampel}

Populasi merupakan gabungan dari seluruh elemen yang berbentuk peristiwa, hal atau orang yang memiliki karakteristik yang serupa yang menjadi pusat perhatian seorang peneliti yang dapat dipanjang menjadi semesta pilihan (Ferdinand, 2006). Pada penelitian ini populasi mengacu pada wisatawan yang sudah berkunjung ke Dusun Bambu, Bandung. Dalam menentukan jumlah sampel pada penelitian ini dengan menggunakan rumus Slovin, maka diperoleh jumlah sampel sebanyak 100 wisatawan. Dalam penelitian ini yang dapat dijadikan sampel yaitu wisatawan yang sudah mengunjungi Dusun Bambu Bandung dan Wisatawan Domestik dan berusia > 17 Tahun.

\section{Metode dan Teknik Pengumpulan Data}

Penelitian ini menyebarkan 100 kuesioner kepada 100 wisatawan yang telah mengunjungi Dusun Bambu, Bandung untuk mendapatkan data penelitian. Pertanyaan disajikan dalam bentuk kuesioner berupa pertanyaan tertutup. Masing-masing pertanyaan dibuat dengan menggunakan skala Likert, yang berisi pertanyaan mengenai Daya Tarik pada Dusun Bambu, Bandung yang disebarkan kepada responden.

Teknik pengumpulan data yang digunakan dengan cara :

1. Observasi

Menurut Sugiyono (2010), observasi sebagai salah satu teknik pengumpulan data yang mempunyai ciri yang spesifik bila dibandingkan dengan teknik lain. Observasi yang dapat dilakukan pada penelitian ini yaitu dengan melakukan pengamatan pada 
lokasi penelitian di Dusun Bambu, Bandung yang tujuannya untuk mengamati ketertarikan wisatawan pada objek wisata tersebut.

2. Wawancara dan Kuesioner

Menurut Endang Danial (2009), wawancara merupakan teknik pengumpulan data dengan cara mengadakan dialog, tanya jawab antara responden dengan peneliti secara sungguh-sungguh. Wawancara yang dilakukan pada penelitian ini dengan cara mencari informasi mengenai Dusun Bambu, Bandung. Kueisoner yang dilakukan dalam penelitian ini dengan memberikan beberapa pertanyaan untuk mengetahui faktor apa saja yang mempengaruhi wisatawan untuk berkunjung.

3. Studi Literatur

Endang Danial (2009), menjelaskan bahwa studi literatur dilakukan dengan cara mengumpulkan data dalam bentuk teori-teori pada buku, majalah, berita, yang berhubungan dengan tujuan penelitian. Studi literatur pada penelitian ini dengan mencari teori yang berhubungan dengan masalah pada penelitian ini.

\section{HASIL PENELITIAN DAN PEMBAHASAN}

\section{Deskripsi Karakteristik Responen}

Dalam penelitian ini jumlah responden sebanyak 100 wisatawan, dengan 59\% wisatawan wanita dan $41 \%$ wisatawan pria. Usia yang paling banyak yaitu kisaran antara $22-26$ tahun sebesar 46\%, yang melakukan wisatawan bersama keluarga.

\section{Potensi Daya Tarik Wisata Dusun Bambu, Bandung}

Daya tarik wisata yang diberikan oleh Dusun Bambu, Bandung yaitu dengan menyediakan banyak pilihan kafe dengan konsep yang berbeda. Selain konsep yang unik, Dusun Bambu juga memberikan suasana yang sejuk dikarenakan berada di bawah kaki Gunung Burangrang. Berdasarkan hasil penelitian wisatawan yang berkunjung karena tertarik dengan desain dan konsep kafe yang ada di Dusun Bambu, Bandung. Terdapat 4 konsep yang ditawarkan kepada wisatawan jika ingin menikmati kafe yang ada di Dusun Bambu, dan masing-masing konsep memiliki keunikan tersendiri. Konsep kafe yang ada di Dusun Bambu seperti Cafe Burangrang yang memiki keunikan saat pengunjung datang bersantai saat makan dan minum mereka dapat menikmati keindahan pemdangan, bukan hanya pemdangan saja yang dapat dinikmati wisatawan dapat menikmati kuliner tradisional khas sunda, hingga kuliner mancanegara. Selain keunikan dan keindahan dari Cafe Burangrang, ada keunikan lain yang ditawarkan oleh Dusun Bambu yaitu Lutung Kasarung.

Konsep Lutung Kasarung ini menjadikan kafe ini sebagai antimainstream, karena pengunjung dapat menikmati saat makan dan minum di dalam kapsul raksasa yang terbuat dari akar dan ranting pohon. Kapsul-kapsul ini ditopang oleh empat pilar bambu sehingga berkesan melayang di atas tanah. Dengan konsep seperti itu menjadi daya tarik pengunjung untuk menikmati konsep yang berbeda dan berfoto-foto di Lutung Kasarung ini. Tidak hanya kafe, di Dusun Bambu juga terdapat konsep Pasar Khatulistiwa. Disini pengunjung dapat berbelanja sayuran dan buah-buahan yang segar karena buah dan sayurnya dipanen langsung dari Gunung Burangrang. Selain itu di pasar ini pengunjung dapat membeli makanan lainnya seperti mie kocok, rujak, surabi dan makanan kuliner lainnya. Salah satu konsep yang unik lainnya dari Dusun Bambu ini yaitu Saung Purbasari yang merupakan konsep fasilitas saung yang dapat menampung 6-12 orang. Disaung ini pengunjung dapat bersantai untuk menikmati makanan dan minuman sambil menikmati keindahan udara yang segar dan 
pemandangan danau. Namun jika ini ke Saung Purbasari pengunjung harus menyebrangi danau dengan menggunakan perahu.

Selain konsep dari Kafe, di Dusun Bambu pengunjung dapat menikmati Play Ground yang dinamakan Bamboo Play Ground yang menyediakan permaian-permainan teradisional. Pada Play Ground ini banyak anak-anak yang menikmati permainan ini, sehingga anak-anak tidak merasa bosan dan jenuh ketika berada di Dusun Bambu. Selain permainan tradisional, di Bamboo Play Ground juga menyediakan pengalaman kepada anak-anak untuk menanam padi, menjelajah alam, dan belajar tali-temali. Banyak pengalaman edukasi yang dapat diberikan pada play ground ini, sehingga Dusun Bambu menjadikan tempat wisata keluarga. Berdasarkan daya tarik pada atraksi wisata yang ada di Dusun Bambu, 47\% wisatawan menyukai konsep dari Lutung Kasarung karena menurut wisatawan konsep tersebut antimainstream dan unik sehingga banyak pengunjung tertarik untuk makan dan minum dengan konsep tersebut dan dijadikan salah satu objek untuk berfoto-foto, sedangkan untuk $28 \%$ pengunjung tertarik memilih konsep dengan Saung Purbasari. Rata-rata yang menyukai dari saung ini yaitu pengunjung yang datang bersama keluarga karena di saung ini pengunjung dapat berkumpul bersama keluarga, karena kapasitas dari saung ini yaitu 6-12 orang. Ada 15\% pengunjung menyukai dari konsep Cafe Burangrang, yang pengunjung dapat bersantai-santai sambil menikmati kesejukan udara di Bandung dan menikmati keindahan alam sekitar. Sedangkan $10 \%$ pengunjung tertarik untuk bersantai di Pasar Khatulistiwa karena disini dapat menikmati kuliner berbagai macam makanan, mulai dari masakan sunda hingga masakan modern.

Selain desain konsep dari tempat makan ini, lokasi dari Dusun Bambu menjadi daya tarik karena lokasi yang mudah di akses dan dijangkau walau lokasi ini tidak berada di pinggir jalan raya, selain itu keindahan alam dan pemadangan dari Dusun Bambu menjadi daya tarik pengunjung untuk datang. Namun dari segi biaya menjadi pertimbangan pengunjung untuk datang kembali ke Dusun Bambu ini karena biayanya tidak murah untuk datang kesini sambil menikmati makanan dan minuman yang dijual di Dusun Bambu ini. Dari segi fasilitas Dusun Bambu sudah menyediakan segala fasilitas seperti toilet yang bersih, musholla, playground untuk permainan anak, fasilitas untuk menginap dll.

\section{KESIMPULAN}

Berdasarkan hasil penelitian dan pembahasan mengenai Daya Tarik Unggulan Ekowisata Dusun Bambu, Bandung sebagai berikut :

1. Dari konsep yang diberikan pada tempat untuk makan dan minum atau kafe, sebanyak $47 \%$ pengunjung menyukai konsep dari Lutung Kasarung, karena menurut mereka ini konsep yang unik dan antimainstream sehingga konsep ini menjadikan daya tarik tersendiri untuk wisatawan berkunjung ke Dusun Bambu

2. Lokasi dari Dusun Bambu yang mudah di jangkau menjadi salah satu faktor yang dipertimbangkan untuk berkunjung, namun berdasarkan hasil wawancara untuk menuju ke Dusun Bambu sulit dijangkau jika tidak menggunakan kendaraan pribadi karena letaknya yang agak jauh dari akses transportasi umum.

3. Pemandangan alam yang indah dan suasana yang sejuk menjadi salah satu faktor pengunjung untuk datang ke Dusun Bambu. Udara yang sejuk karena letak Dusun Bambu di bawah kaki Gunung Burangrang.

4. Umumnya pengunjung yang datang bersama keluarga sangat menyukai konsep dari playground yang tersedia di Dusun Bambu, sehingga anak-anak bisa main di 
Playground orang tuanya dapat menikmati dan bersantai di tempat makan dan minum dengan konsep yang unik dan berbeda dengan tempat wisata lain.

5. Untuk biaya menjadi salah satu faktor yang paling terendah, karena biaya untuk ke Dusun Bambu tidaklah murah, apalagi harga makanan dan minuman yang ditawarkan di Dusun Bambu dapat merogok kocek yang lumayan.

\section{DAFTAR PUSTAKA}

Ali, J. A., \& Howaidee, M. (2012). The impact of service quality on tourist satisfaction in Jerash. Interdisciplinary Journal of contemporary research in business, 3(12), 164-187.

Ferdinand, A. (2006). Metode penelitian manajemen.

Basiya, R., \& Rozak, H. A. (2012). Kualitas Dayatarik Wisata, Kepuasan Dan Niat Kunjungan Kembali Wisatawan Mancanegara Di Jawa Tengah. Jurnal Ilmiah Dinamika Kepariwisataan, 11(2).

Damanik, J., \& Weber, H. F. (2006). Perencanaan ekowisata: Dari teori ke aplikasi. Yogyakarta: Puspar UGM dan Andi.

Danial, E., \& Wasriah, N. (2009). Metode Penulisan Karya Ilmiah. Bandung: Laboraturium Pendidikan Kewarganegaraan.

Tarsito, S. (2014). Metode Penelitian Kuantitatif, Kualitatif dan R\&D. Alfabeta. Bandung.

Warpani, S. P. Dan Indira P. Warpani. 2007. Pariwisata dalam Tata Ruang Wilayah.

Yoeti, O. A. (2010). Undang-Undang Kepariwisataan 2009: UU RI No. 10 Th. 2009. 